\title{
THE PROTÉGÉ AND THE SAGE: STUDENTS' PERCEPTIONS OF WORK-BASED MENTORING EXPERIENCES
}

\author{
Dr Maureen Harris \\ $\mathrm{PhD}$
}

Associate Director, Department of Postgraduate Nursing Studies, Ritson Campus, Durban University of Technology, Durban

Corresponding author: maureenh@dut.ac.za

Keywords: mentor; mentee; work-based learning; scaffolding learning

\begin{abstract}
Mentoring is offered as a supportive learning strategy within an educational programme for mature multi-cultural South African nurses. This paper considers the literature, describes mentoring within a nursing management course, and uses the findings to illustrate students' mentoring experience through the following three themes: (1) Mentoring as a teaching strategy: Initial considerations; (2) Mentoring as a process; and (3) Consequences of mentoring as a teaching strategy. Self-reports, based on two questions, describe the perceptions 16 post-basic students have of mentoring as a means of scaffolded learning through the voicing of their 'authentic' experiences. This study forms a component of a larger qualitative case study of a management course using action research within the critical genre. A way forward is suggested that can promote both the mentor/mentee relationship and meaningful learning. Students paid particular attention to the difficulties of choosing mentors, engaging in and 'negotiating' the process and maintaining the relationship. They recognised the value of 'special people' (not necessarily in their discipline), in their professional development and noted the need for mutual commitment to the process to achieve mutual benefits.
\end{abstract}

\section{OPSOMMING}

Mentorskap word aangebied as 'n ondersteunende leerstrategie binne ' $n$ onderwysprogram vir volwasse multikulturele Suid-Afrikaanse verpleegkundiges. Hierdie artikel handel oor die literatuur, beskryf mentorskap binne ' $n$ verpleegkundige bestuurskursus en gebruik die bevindinge om studente se ondervinding van mentorskap deur die volgende drie temas te illustreer: (1) Mentorskap as 'n onderwysstrategie: Inisiële oorwegings; (2) Mentorskap as ' $n$ proses; en (3) Gevolge van mentorskap as 'n onderwysstrategie. Selfrapporte, gebaseer op twee vrae, beskryf die persepsies wat 16 nagraadse studente van mentorskap het as ' $n$ wyse van ondersteunende leer deur die uitdrukking van hulle 'outentieke' ondervindinge. Hierdie studie maak 'n deel uit van 'n groter kwalitatiewe gevallestudie van ' $n$ bestuurskursus en maak gebruik van aksienavorsing binne die kritiese genre. Riglyne word gebied wat die verhouding tussen beide die mentor en die persoon wat die mentorskap ontvang kan bevorder en betekenisvolle leer kan bewerkstellig. Studente gee spesifieke aandag aan die probleme daaraan verbonde om mentors te kies, betrokke te raak by die onderhandeling van die proses en die handhawing van die verhouding. Hulle erken die waarde van 'spesiale persone' (nie noodwendig in hulle dissipline nie) in hulle professionele ontwikkeling en neem kennis van die behoefte van wedersydse betrokkenheid by die proses om gemeenskaplike voordele te verkry. 


\section{INTRODUCTION}

The unsuccessful traditional delivery of a course in nursing management at a university of technology called for a change in methodology. As a result, an innovative approach to teaching and learning was implemented. This required a parallel investigation, culminating in a three-year case study of this course framed within a participatory action research design. This article deals with a component of this study, the exploration of students' perceptions of mentoring, one of the strategies within the new approach.

\section{Framing the problem}

There is no doubt that many nurses in South Africa are feeling frustrated and exhausted. They are faced by problems seldom confronted by nurses in health systems in the better resourced western world (Industrial Health Research and the SA Municipal Union, 2005:31). These challenges take place:

- in environments where many of the nurses face increasing work burdens and where their help is often only palliative, resulting at times in a mechanistic approach to nursing. This often seems to engender feelings of helplessness and a sense of alienation, preventing nurses from truly connecting with their patients or finding the space to question their practice (Harris, 2006:2, 734). Frustrations are evidenced by an exodus of nursing staff (Lehmann \& Sanders, 2002:129).

- where students' previous learning experiences are rooted in the more traditional educational backgrounds that historically rated proficiency in the tasks of nursing above that of knowing nursing. This impacts on their ability to practice autonomously (Radebe, 2000:5-7; O'Shea, 2003:62).

- in higher education institutions where efforts to maximise educator resources have resulted in increased student-teacher ratios and reduced individual student contact. The limited learner contact is exacerbated by the inability of health services to release nurses for further study, due to staff shortages or workloads (Gwele, 2003:15).

In response to these changing and challenging contexts, there is a strong move away from the traditional transmission approach used in contact sessions to independent and learner centred techniques - especially for adult learners in higher education (Chabeli, 2002:49).

\section{Context of the study}

The focus of the case study was on the teaching approach in a one-year learning course in nursing management in a department of nursing in a tertiary education system. It had been offered in a traditional lecturing format.

Feedback from local health services showed that while students were theoretically competent, application in the real-world setting was problematic.

A situational analysis revealed the students as multicultural, multi-lingual registered nurse practitioners, whose ages ranged between 23 and 58 . They were all very busy, with limited time for studies, both in the classroom and at home. On the other hand, they were adult learners with clear learning goals, and multiple nursing experiences. These factors and the challenges arising from complex health and educational systems determined a new approach to the course, with the introduction of a critical reflective practice framework underpinning a three-year participatory action research study of the nursing management course (Van Aswegen, Brink \& Steyn, 2000:117-135). One of the educational supports within this framework was a work-based mentoring strategy.

The students were registered nurse practitioners working in a variety of health care settings. Each of their workplaces had its own ethos. Therefore learning within the actual work context should allow students to better understand, affect and be affected by the ethos of their organisation in terms of attitudes, behaviours and standards. One of the ways in which this development could be effected would be through the mentoring process. It was assumed that if students, who had very limited class contact time, could choose their own mentors and engage in supportive relationships, this would enhance authentic learning experiences within the workplace setting. This study will look at the 16 students views on mentoring, elicited in the form of selfreports.

There is a paucity of research investigating mentoring 
in nursing in South Africa. The mentoring approach in this nursing management course was unique as students worked in different institutions, chose their own mentor (a voluntary unpaid arrangement) and had the freedom to negotiate the ensuing relationship, their learning needs and how these would be met within this context. Students could choose more than one mentor, from both within or outside of their discipline and work setting.

\section{Mentorship and preceptorship differenti- ated}

Mentoring in this study, is a relationship in which a more experienced person (the mentor) contributes directly to the growth and development of the less experienced or inexperienced person (the mentee), usually in the workplace (Smith, Howard \& Harrington, 2005:32). It is a reciprocal, mutually agreed upon, caring relationship where both people need to like and respect each other. The prime focus is on personal and professional growth which takes time, and is determined by the holistic learning needs of the mentee, and not curriculum objectives. The intention for fostering this relationship was to provide a space and sounding board for reflection on practice to occur.

Mentorship is not common practice in South African nursing. It should not be confused with preceptorship, an accepted method of clinical accompaniment, guidance and supervision of students in clinical settings (Greene \& Puetzer, 2002:68). Preceptorship is frequently used in South Africa where student nurses undertake their experiential learning in a variety of health care settings. Because these are usually decentralised, the educational nursing department appoints preceptors, customarily experienced nurses with clinical expertise, who act as role models. They will guide, teach and evaluate the students, directed by curriculation objectives (Phillips \& Duke, 2001:524). Preceptors liaise with students, health service staff and are accountable to the educational institution. This is usually a short-term engagement (Northcotte, 2001:30).

\section{An overview of the mentoring process}

According to East (1995:120), if nursing is to claim the title of profession, the novice nurse must be prepared for a role that incorporates and encourages autonomy.
Mentoring programmes need to encompass not only the development of competent clinical nurses, but also the development of an individual's ability to become self-directing and thoughtful. Mentoring programmes offer opportunities, founded on the concepts of adult learning, to enable newer entrants to the specified field of nursing, to make a smoother transition from novice to knowledgeable practitioner.

Barnard (2002:36) suggests that the mentor also helps the mentee navigate the political landscape of the work environment by making introductions to key personnel and opening previously closed doors to and within the system. This is particularly valuable in nursing, generally regarded as a highly structured, hierarchical profession with specific norms and multiple policies and procedures for operating within the culture of that profession. But it is the informal associations made outside of the hierarchical context that are more conducive to developing the relationship. Zey (in Sarnier, 2000:93) corroborates this need by suggesting that the process is likely to be high-jacked within a rigid hierarchical organisation because of the need to conform to the hidden norms implicit in the culture of that system.

East (1995:120-121) views mentoring as a bridging process between theory and practice which goes beyond induction and training to that of continuing professional development for practitioners and managers. "The stronger the bridge, the more confident the mentoring pair and the more frequent the journeys across the bridge, backwards and forwards, from not knowing to knowing, from not understanding to understanding, in an ongoing process until eventually theory becomes integrated into practice". The purpose of this process is to enable the mentee to become an autonomous professional who is both self-reflective and self-directing.

Mentoring is not a concept that can be clearly categorised and contained. There is fluidity in the relationships and the role. Northcotte (2001:31) has identified five types of groupings where mentoring can take place. These include (1) nurses still in training, (2) nurses returning to practice, (3) nurses from a different country needing help with adaptation, (4) newly qualified nurses and (5) established practitioners. The nurses (mentees) in this study were an amalgam of two groups: they were established practitioners but they were still stu- 
dents in the process of learning.

A mentor is a trusted and friendly advisor or guide, especially of someone new to a particular role. In classical terms, the mentor becomes involved in a powerful interpersonal relationship with a less experienced, normally younger person. Darwin (2000:197) however suggests that this is a narrow, functionalist perspective. It should not apply to a study such as this where a more "critical or radical humanist" perspective is valued as it is one that prevents unequal and sometimes exploitative power relationships. In the case of many of the nursing management students, the mentees, were less experienced in the specific specialty, but were not necessarily younger, and certainly not inexperienced in nursing per se. So in this context, career-age rather than chronological age becomes more relevant (Darwin, 2000:107). The mentor usually represents knowledge, reflection, insight, understanding, good advice, determination and planning - qualities which cannot easily be mastered alone. Using the metaphor of a journey, the mentor acts as a travelling companion who is more of a trusted guide than a tour director.

A successful mentoring relationship is vital to the process. The mentor protects, urges forward, explains mysteries, points the way, leaves the mentee alone when necessary, translates codes, clears obstacles and encourages - always encourages - helping the mentee find the courage within herself to go on. This is a relationship between two people and what distinguishes fine mentors is their ability to care, suggests East (1995:121). The mentor engenders trust, offers vision, and alternatively supports and challenges the mentee (Northcotte, 2001:31-32). Allen (2002:440) identifies three key aspects in a successful mentoring relationship: mutual respect and trust between mentor and mentee; a facilitative environment of "understanding, empathy, and cooperation; and mutual sharing of information through good communication skills". Beyene, Anglin, Sanchez and Ballou (2002:100) also stress the importance of this relationship and their study underpins the focus on the mentor-mentee relationship particularly in terms of establishing what Darwin (2000:207) identifies as the "horizontal relationship." This is where a climate of risk-taking and dialogue is instituted to create new knowledge so that mentoring becomes "a collaborative, dynamic, and creative partnership of co- equals, founded on openness, vulnerability, and the ability of both parties to take risks with one another beyond their professional roles" (Darwin, 2000:207). This opens opportunities to share and discuss at levels where the boundaries between expert and learner become blurred, because of the interdependence and maturity of the relationship so that the vertical interaction transcends to a horizontal one of collegiality (Darwin, 2000:206).

This interactive alliance points to the mentee's role in this relationship. Greene and Puetzer (2002:69) believe that it is the mentees' responsibility to be open to receiving help; to be open to learning and caring; to be committed to their profession; to have a desire for competence and to demonstrate initiative and a strong sense of self. The mentees also need to understand their health service and the barriers to learning within their work context. Barnard (2002:36) clarifies their organisational role in this relationship as one where mentees are responsible for their own development, where they set their own agendas and organise the meetings with their mentors. They are also required to have a personal plan, ask for honest feedback and be committed to the relationship.

This relationship does, however, have boundaries. The mentor eventually needs to 'let go' of the mentee and good mentors ensure that their mentees can recognise that authority is useful but limited and that the task of becoming independent involves separation from the authoritative figure and taking on one's own authority. Grey and Smith (2000:1547) identify the value of mentoring, but also focus on the very natural gradual distancing which occurs over the process of time and the learning which results in changes in the relationship. Traditional patterns of mentoring recognise the separation phase, but this is connected to the original concept of mentoring of young men by older, more experienced men and does not take into account the type of relationships engaged in by women. Darwin (2000:206) cites Gilligan's 1982 research which "suggests a fusion of identity and intimacy for women, rather than identity preceding intimacy. Developmental theory has established men's experience and competence as a baseline against which everyone's development is judged, often to the detriment or misreading of women...". Distancing is not about withdrawal of intimacy but handing over of position of authority. So, sepa- 
ration does not necessarily mean a physical and emotional distancing, but rather a reshaping and readapting to a new, perhaps more intimate friendship. True mentoring of a classical nature is the holistic support for the individual in the development of a new and complex professional role.

\section{RESEARCH QUESTION}

This article reports on one component of a larger threeyear qualitative case study of the nursing management course using a participatory action research design within the critical genre. This component focuses on

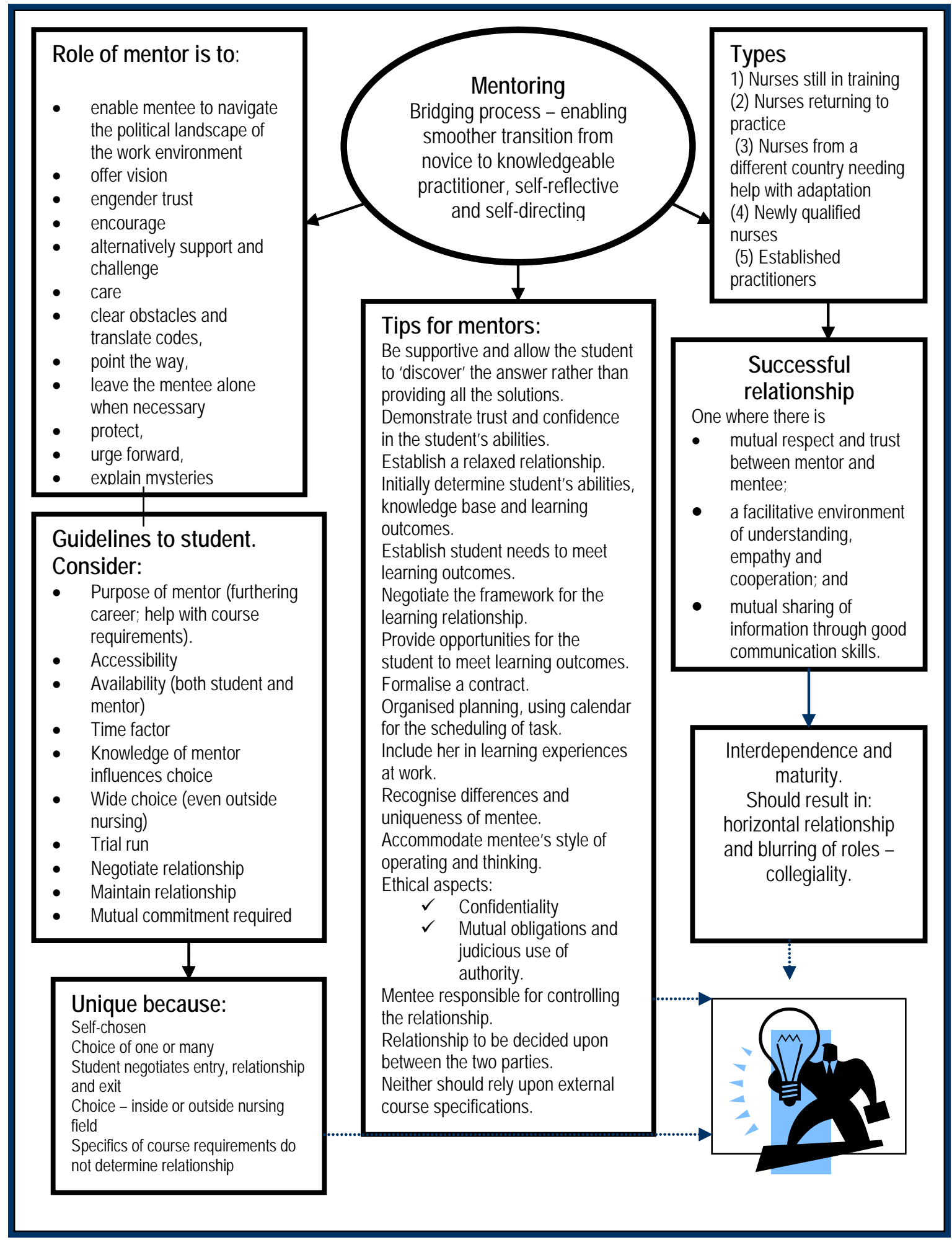

Figure 1: Mentoring system 


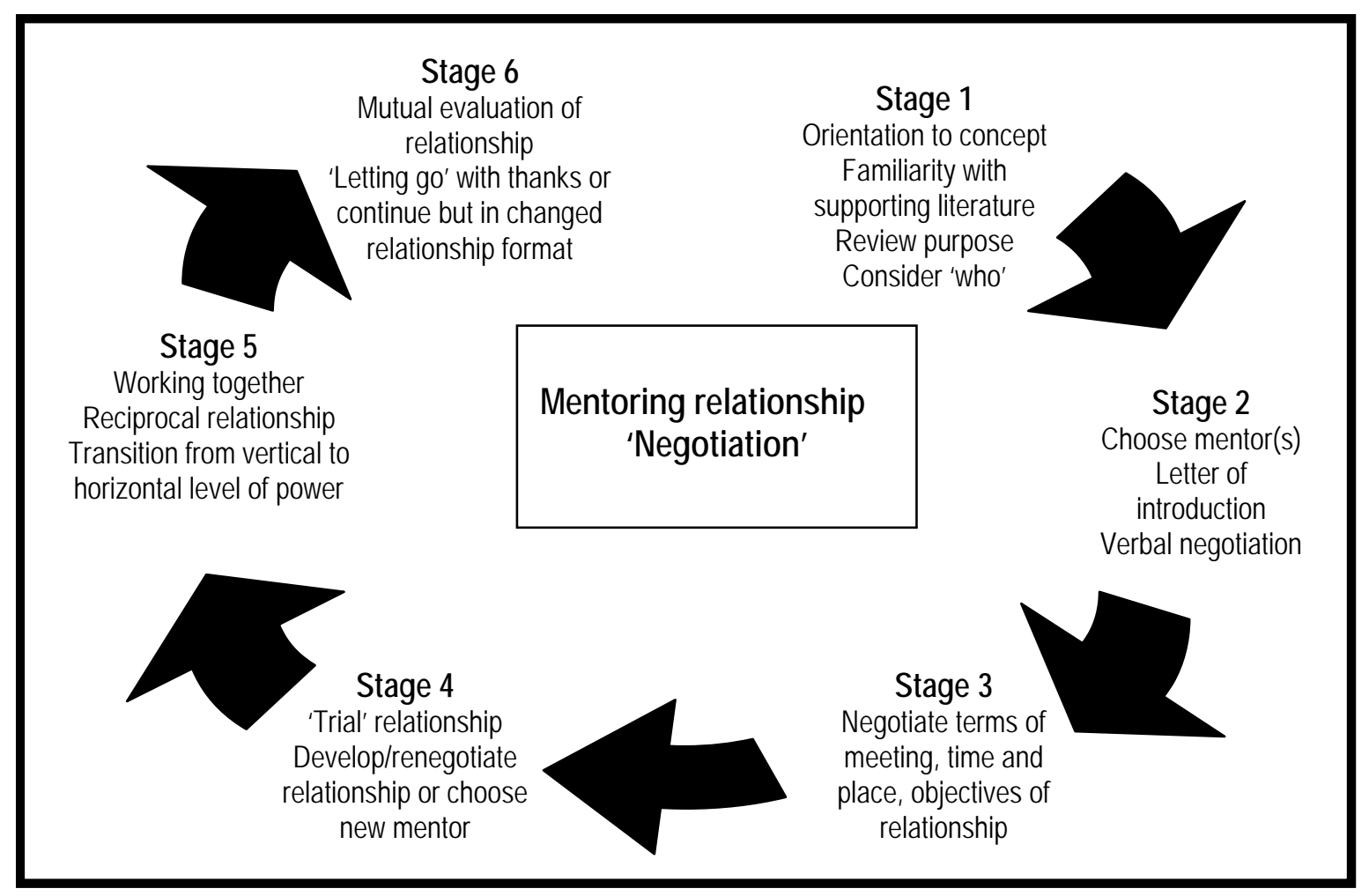

Figure 2: Mentoring relationship process

nursing students' perceptions of the value they placed on their mentoring experiences and was driven by the research question: How do students experience their mentoring process? The findings are used mainly to illustrate a discussion on mentoring as an educational scaffolding method.

\section{METHODOLOGY}

\section{Population and sample characteristics}

The study population for the total three-year case study comprised 75 students. Sampling was "within case" (Miles \& Huberman, 1994:29) of the student group at the end of the second year of the research cycle, in order to evaluate and refine selected teaching strategies for the final year. The student mix of the sampled group of 16 students reflected the local racial demographics (11 Black, two Asian and three White) of practising female nurses with an average work history of 15 years in a variety of health care services ranging from deep rural to urban settings. The students had returned to study in a post-basic degree programme, comprising two years of part-time academic study. This built upon students' foundational three (or four) year basic nursing training generally situated in nursing colleges where teaching had tended to be didactic (Simelane, Kunene \& Mhlongo, 1997:11-14). Class contact time was limited to 32 days in the academic year. Nine of the 16 nurses were single parents and all had onerous responsibilities including family, community, occupational and study commitments. The intention was to support nurses working in a problematic health care system by facilitating their learning in a way that would prove meaningful and valuable to their practice.

\section{Data collection}

Institutional ethics guided the study. Trustworthiness, authenticity and accuracy were established through peer debriefing (there were three critical readers), triangulation (data source, theory, investigator and method triangulation) and a comprehensive data trail. The researcher's/educator's reflexive journal comprised detailed weekly entries of descriptions and analyses over the three-year research period. This persistent observation and prolonged engagement helped enhance both the scope and depth of the research focus (Polit \& Hungler, 1997:304-308). 
Only one group of students was sampled over the one academic year. These sixteen students' self-reports were derived from the following questions: Discuss the value and limitations of your experience of the mentoring process this year. Explain what I did to make this an effective experience and what I should have done to make it a better experience?

These questions formed part of a larger questionnaire completed at the end of the learning course, the purpose of which was to obtain a clearer understanding of students' perceptions of some of the selected strategies. The questions formulated were informed by the literature, personal experience and validated by two educators and researchers. The larger questionnaire comprised a four-page series of closed and open-ended questions relating to specific educational strategies used in the course, such as students' virtual on-line classroom, their workbooks and their orientation to reflective practice. Two questions were asked on mentoring, and it is the data generated from these that are discussed in this article.

\section{THE STRUCTURING OF THE MENTOR- ING PROCESS WITHIN THE STUDY}

Students were expected to identify a manager from within or without the students' nursing discipline or workplace who was prepared to act as a mentor for them during the course. The purpose of the mentor was to facilitate better understanding about and access to the student's work context and to support the student through the learning process by providing access to information and acting as a sounding board for ideas. Students were expected to establish entry into the system and to motivate for such a mentor, with whom they would need to meet at least twice a month. They were also required to 'negotiate' and draw up a contract with their mentor.

The mentoring concept was initiated in this study with varied levels of success. A student-run workshop debated this mentoring process, the intention of which was to explore its purpose, value and implementation. The workshop was also used as an opportunity for students to recognise and appreciate their mentors and the value of their role in students' own personal growth. It became clear that more emphasis needed to be placed on promoting this concept earlier and more fre- quently so that new students would understand the 'how to' and the learning benefits and so engage and 'own' the mentoring process. Further interrogation of the mentoring process took place

- during orientation to the course;

- $\quad$ through a video-taped presentation of the previous workshop;

- through a letter of introduction to the proposed mentor;

- through the development of a negotiated contract with the individual mentors;

- $\quad$ via provided research articles on mentoring;

- in on-going group work about the process by anticipating difficulties and role-playing solutions; and

- through self-evaluation.

\section{FINDINGS: STUDENTS' PERCEPTIONS OF THEIR MENTORING EXPERIENCES}

All students' quotes were transcribed verbatim. The findings were analysed according to the literature and used the techniques of pattern-matching (where patterns are identified within the data and linked to predicted patterns, derived from experience and the literature) and explanation building (where analysis of the data within the case study is carried out, building a case for the case) (Tellis, 1997). Data were categorised and then organised into three themes: (1) Mentoring as a teaching strategy: Initial considerations (2) Mentoring as a process and (3) Consequences of mentoring as a teaching strategy.

\section{(1) Mentoring as a teaching strategy: Ini- tial considerations}

Choosing a mentor was a critical stage in the process but finding a mentor was not an easy task for many students. Not only was the concept new to many of the chosen mentors, but nurses in general, no matter the level, were stressed and found it difficult to set time aside to meet with the student. Compounding the problem was the high turn-over rate referred to earlier by Lehmann and Sanders, (2002:129): "Was quite valuable for the times we met and discussed issues. But it was difficult to meet regularly with the mentor. From the beginning of the course I had problems in getting a mentor. People I talked to were having problems and others left (resigned) before even we started..." (Stu$\operatorname{dent} A)$. Student $B$ recognises the value of self-choice 
of mentors as follows: "The concept of the student choosing their own mentor is recommended as they themselves will only know how accessible this person would be to them". Ziegahn (2001:5) and Oliver and Aggleton (2002:36) suggest that mentoring of students in the workplace by mentors of a similar culture is helpful in allowing the student an alternative, more empowered voice. They note that this is one of the ways in which educators can promote an appreciation of the cultural diversity amongst students. This was particularly important for facilitating this group of nurses, many of whose cultural backgrounds were dissimilar to that of the facilitator/ researcher.

It is difficult to be sure that the first choice of mentor is the correct one and so some students 'trialled' their mentor: Student C made a suggestion: "Difficult to decide who to choose - sometimes initial choice turns out to be unsuitable. I have a couple of structured sessions with 2-3 potential mentors before making a decision and commitment to one. The first session could have structured questions to be asked, so as to initiate discussions - help, point the way for future sessions. Often time a problem and times became informal frequent "chats" rather than structured time together".

Familiarity promoted the trust that East (1995:121) suggested was needed in the relationship. "My mentor served as a familiar face guiding my studies. This made her approachable and dispelled the fear of burdening her with my deficiency in understanding of the course content" (Student D).

It becomes relatively easy to embrace a method that is tried and true, but this was a new approach to a learning experience for each student. Not only did they have to negotiate with their mentor, they had to develop a self-realisation about the mutuality of the responsibility espoused by Greene and Puetzer (2002:69). Notes Student F: “... all depended to me as a student and my mentor to make it work effectively".

Students realised that the relationship was an informal one and if it was to work, both parties needed to be committed. Student E stated that "There has to be commitment on the side of the protégé as well as the mentor". This was difficult when the student had to do her own negotiating, and obviously, with both parties working, time became a factor. Despite earlier discussions around flexibility in choice of mentor, Student $O$ regretted not having been more creative in her choice or not having looked closer to home where access and expertise were available: "My mentor was in a new position and a very busy one and really hadn't the time to support. But was always available to view work done or give advice. I regret not asking my brother, retired this year, to act as mentor, as he would have been wonderful...".

Finding the right mentor makes the learning process that much more valuable: "...Until toward the end I found a dedicated person who even sacrifice her time to assist in my studies. ... I wished I met her from the beginning" (Student K).

\section{(2) Mentoring as a process}

Some students who felt that the process was too 'loose' asked for more formalised guidelines. "It may be useful if (facilitator) was to make available a 'mentor guide' in which goals are set, to give guidelines" (Student G). The constructivist self-directed approach to education formed part of the critical reflective model used in the management course. In this approach, the ideas outlined are presented as broad concepts and then deconstructed into smaller parts and students are encouraged to question, analyse and form their own conclusions (Hanley, 1994). After deconstructing the mentoring concept, the students were expected to form their own reconstruction of guidelines based on their own needs. This student is just reflecting her newness to a constructivist teaching style, so in future, although a structured guide will not be provided, students will have more opportunities to reflect on this aspect. Student $\mathrm{H}$ bemoans the lack of teacher direction: "No properly guidance if you do things on your own" but ultimately realises that what she should have done was to: "Ask the manager of the unit to place me as a deputy manager so that I can function and practice managerial skills. Consulted the expertise whenever I need information, not to suck it out of the thumb ...".

In those classes where the facilitator has either not had the time or inclination to explore the process with individual students, it is very easy for students who have not been able to find a mentor or establish a sturdy relationship, to disengage from the process (personal 
observation). This reflection is supported by Student M who recognises the value of motivation to maintain interest and the relationship: "Mentoring process was made an effective experience since our course facilitator kept asking questions from us in the classroom as to how we were doing in our practical situations and how we related with each other. It stimulated interest and improved communication, because we always looked for what we can report on in the class which can be of help to everyone if discussed in the classroom".

Relationships take time to build and develop and this has to be carefully factored into student planning. This was difficult when both mentor and mentee worked, especially in different places: "I didn't get mentor on time and even the one I had was working in the municipality while I am working in provincial hospital so we were not meeting frequently because of time. You kept on encouraging us to find a mentor" (Student I).

Maintaining the relationship is another critical phase in the process. Student $\mathrm{O}$ echoes the time limitation but offers a solution that allows her to move past the role of 'student needing help' to a collegial role which reduces non-engagement because a deeper connection is made: "... One of the difficulties I found was to maintain the mentorship relationship as my mentor was always too busy. I found the best way to overcome this was to 'deformalise' the process and discuss issues with her over a cup of coffee, rather than keep a fixed appointment which she was unable to keep".

Student I make a case for frequent meetings. "My mentor was an immense help as he made time for me on an average of twice weekly. We discussed issues ... which made understanding easier...".

Not all students realised that they personally would need to negotiate the relationship: "Maybe if you can have the mentors phone you at least once and give them an idea of what you would like them to help the students with" (Student J). Mentors were purposefully not co-opted as students needed to negotiate the relationship and decide on their own learning needs. Additionally, this was not a formal appointment. The mentoring process was voluntary and entailed no form of payment. Walters, Clarke, Ingall and Dean-Jones (2003:524) in their study on a mentoring programme for new nurse managers, support the need for mentees to choose their own mentors in their own way and in their own time.

\section{(3) Consequences of mentoring as a teaching strategy}

Choosing someone outside the discipline of nursing is useful as it enables the students to think 'outside the box' of nursing. Wider exposure often means different ideas. Student $P$ discusses the mutual benefits of the relationship as well as the feeling of safety engendered by a contract: "My mentor is my HR manager - it made him feel important - good for his self-esteem. I gained from his input and stimulation and challenges of thinking along different lines. Overall very beneficial - good to have a 'contract' with someone to bounce things off'.

Part of the learning process is also the negotiated entry into this relationship. There are mutual benefits (Beyene et al. 2002:87) resulting in professional growth. (Chovwen 2004:127). Greene and Puetzer (2002:63) provide reminders of how knowledge can be achieved in the context of this relationship, initially by the student engaging in formal classes, then through a "review of policies and procedures before undertaking a new task, text and journal reading for key concept learning, self-study modules, critical thinking exercises, and tests. Attitudes are shaped through role playing, open concept thinking, case study review, feedback sessions, and value clarification exercises".

Professional development should ensue from an effective relationship. Beyene et al. (2002:87) and Chovwen (2004:127) link mentoring to career success. Darwin (2000:204) points out the resultant increased organisational productivity and leadership development. Student K elaborates: "Mentoring proved to be beneficial in executing most of my work. Although the contact session was so little with my mentor but the conversation telephonically and the written material supplied to me assisted me a lot in my work. This have encouraged me and taught me to be able to stand on my own and contributed a lot towards my independent abilities".

This strategy promotes integration of theory and practice. One of the benefits of choosing volunteer mentors from the health services is that it also validates the connection of the learning programme to management 
concepts at health service level in a real way. The tacit knowledge about the organisation also becomes explicit. Student J notes: "I have been able to have a taste of the difficulties managers have".

Student M affirms Barnard's (2002:36) view that mentors can help their protégés negotiate political landscapes and it is also quite obvious that by strategically placing her boss in the mentoring role, Student $M$ is able to soften the traditional rigid employer/ employee relationship boundaries: "I had just joined the Company and it was very important for me to have a mentor, my boss, who informed me about the company, who encouraged me during the course and was a fantastic source of information".

\section{RECOMMENDATIONS ON THE MEN- TORING PROCESS}

\section{Formal teaching for mentors - or not?}

Oliver and Aggleton (2002:36) indicate that specific training in mentoring will be helpful in alleviating some fears identified in their literature review by mentors, such as lack of preparation, lack of support and feelings of being overwhelmed by mentee's personal problems. However, this may not be the correct approach, particularly if students are required to negotiate entry and establish their own boundaries and frames of reference. Students are advised to share the hand-outs on mentoring with the mentors. Although an introductory letter does offer clarification and support on request, students should be advised to reinforce this offer for those mentors who specifically request support.

\section{Guidance}

One of the students identified a need for guidance for the mentor which could be sourced from undergraduate students' recommendations in the study of Grey et al. (2000:1547):

- Be supportive and allow the student to 'discover' the answer rather than providing all the solutions.

- Demonstrate trust and confidence in the student's abilities.

- Establish a relaxed relationship.

- In the early stages, determine the student's abilities and knowledge base and her intended learning outcomes.
- Find out what the student needs in order to meet these learning outcomes.

- Negotiate the framework for the learning relationship and try to provide opportunities for the student to meet her learning outcomes.

- Formalise a contract.

- Remember the student when something of interest occurs in the work context or if you can include her in learning experiences for example, management meetings or helping with connections.

Sarnier (2000:94) adds to the last point and suggests that the differences and uniqueness of the mentee's style of operating and thinking should be accommodated so that the mentor can tailor the experiences and discussions, particularly those related to alliances and collaborations. She also draws our attention to the ethical aspects of the relationship focusing on mutual obligations and judicious use of authority (Sarnier, 2000:91). Oliver and Aggleton (2002:37) include the concept of establishing confidentiality and Greene and Puetzer (2002:70) highlight the need for organised planning, using a calendar for the scheduling of tasks. Barnard (2002:38) re-emphasises that the responsibility for controlling the relationship is the mentee's and believes that ideally this particular relationship should be about six to nine months in duration. This would be appropriate for the course of study of nursing management, however, there is no reason that this relationship should not continue or move to a different shape or context, and Sarnier (2000:92-93) is of the belief that a sound mentoring relationship within the workplace may take three to five years to fully develop. Barnard (2002:38) indicates that the discussions should be decided upon between the two parties and neither should rely upon external course specifications.

\section{Tips on finding a mentor}

Flexibility with regards to the choice of mentor(s) is advised based on students' analysis of their work and social environment, in terms of choosing mentors that would most suit their needs. Possible limitations that could be presented by the relationship, for example, limited available time or lack of interest in supporting or promoting student knowledge or accessibility factors, should be taken into account. Students also need to be aware of and look for specific traits in their proposed mentor. According to East (1995:119), these include 
the person to be a well respected, knowledgeable authority who appears, at the outset, to offer support, allay fears of isolation, ignorance and ridicule, and challenge and confront where necessary. The mentor needs to be up-to-date in the field, recognise what lies ahead and forewarn the mentee of what needs to be done. Ideally, the mentor should have a macro perspective of course requirements and be able to demystify the process for the mentee. The mentor should be able to recognise and appreciate the mentee's abilities, act as the mentee's advocate where necessary, provide constructive feedback, promote independence and finally, allow for 'separation' for the development of a changed relationship.

\section{The question of power}

Darwin's (2000:206-7) warnings about power disparities, inequitable relationships and barriers to true learning is particularly related to mentoring as a strategy within the workplace, where it is a formal, regulated, identified strategy of Management. There is a difference in this course of study. The arrangement and choice of mentors is informal and decided on by the student and does not form part of the student's organisation's intent. This immediately places the choice and decision of this learning strategy within the student's grasp. This does not nullify the power differentials, but it does reduce them. Additionally, there is no assessment or accreditation function attached to the mentoring role, which further limits the power relationship (Oliver \& Aggleton, 2002:36).

\section{LIMITATIONS OF THE STUDY}

This article does not attempt to provide generalisable or replicable findings but rather investigates a specific context as it is. Research which looks in depth at the perceptions of a small sample "stresses the importance of discovering the meanings which research participants give to their own activities" (Quinn 1999:54).

\section{CONCLUSION}

Oliver and Aggleton (2002:33) observe that learning occurs through the agency of this mentoring relationship, where one learns with the help of another. People, they suggest, need encouragement and a relationship that allows them to engage in dialogue. Therefore as a scaffolding technique, mentoring appears to be a useful strategy. An investigation of student perceptions of the mentoring process showed that they believed these to be positive, though challenging encounters enhancing their learning experience.

\section{REFERENCES}

ALLEN, LA 2002: Mentoring: The essential connection. AORN Journal, 75(3):440-446.

BARNARD, BM 2002: The benefits of mentoring. Surgical Services Management, 8(4):35-38.

BEYENE, T;ANGLIN, M; SANCHEZ, W \& BALLOU, M 2002: Mentoring and relational mutuality: Proteges' perspectives. Journal of Humanistic Counseling, Education and Development, 41(1):87102.

CHABELI, M 2002: Portfolio assessment and evaluation: Implications and guidelines for clinical nursing education. Curationis, 25(3):4-9.

CHOVWEN, CO 2004: Mentoring and women's perceived professional growth. Ife PsychologIA, 12(1):126-132.

DARWIN, A 2000: Critical reflections on mentoring in work settings. Adult Education Quarterly, 50(3):197-211.

EAST, P 1995: The Mentoring Relationship. (In: Ellis, RB; Gates, RJ \& Kenworthy, N eds 1995: Interpersonal Communication in Nursing Theory and Practice. New York: Churchill Livingstone, pp 119211).

GREENE, MT \& PUETZER, M 2002: The value of mentoring: A strategic approach to retention and recruitment. Journal of Nursing Care Quality, 17(1):63-71.

GREY, MA \& SMITH, LN 2000: The qualities of an effective mentor from the student nurses perspective: Findings from a longitudinal qualitative study. Journal of Advanced Nursing, 32(6):15421549.

GWELE, NS 2003: Globalization and the nursing workforce: The importance of what we care about. A paper presented at the occasion of her inauguration as a professor of nursing at the University of Natal - Durban, 16 September, 2003.

HANLEY, S 1994: On constructivism. Available from http:// www.towson.edu/csme/mctp/Essays/Constructivism.txt (Accessed on 30 May 2005).

HARRIS, M 2006: The integration and development of Van Aswegen's (1998) model of critical thinking, within a nursing programme, to promote critical reflective practice. Durban: Durban University of Technology. (Unpublished D Tech thesis). INDUSTRIAL HEALTH RESEARCHAND THE SAMUNICIPAL UNION 2005: Occasional Papers Series. Number 8:1-54. The state of occupational health and safety of municipal health workers. Available from www.equinetafrica.org/bibl/docs/IHRhres.pdf (Ac- 
cessed on 19 April 2005).

LEHMANN, U \& SANDERS, D 2002: Human Resource Development. (In: Ijumba, P; Ntuli, A \& Barron, P eds. 2002: South African Health Review. Durban: Health Systems Trust).

MILES, MB \& HUBERMAN, AM 1994: An expanded sourcebook. Qualitative data analysis. Thousand Oaks: Sage.

NORTHCOTTE, N 2001: Mentorship in nursing. Nursing Management, $7(3): 30-32$.

O'SHEA, E 2003: Self-directed learning in nurse education: A review of the literature. Journal of Advanced Nursing, 43(1):6270.

OLIVER, C \& AGGLETON, P 2002: Mentoring for professional development in health promotion: A review of issues raised by recent research. Health Education, 102(1):30-38.

PHILLIPS, N \& DUKE, M 2001: The questioning skills of clinical teachers and preceptors: A comparative study. Journal of Advanced Nursing, 33(4):523-529.

POLIT, DF \& HUNGLER, BP 1997: Essentials of nursing research. Methods, appraisal, and utilization. Philadelphia: JB Lippincott.

QUINN, L 1999: An examination of the drafting-responding process used to develop students' writing in an English Language for Academic Purposes Course. Grahamstown: Rhodes University. (Unpublished Master thesis).

RADEBE, G 2000: Policy in Progress: Nurse training for the District Health System. HST Update, 54(August):1-18.

SARNIER, E 2000: Public administration mentorship: Conceptual and pragmatic considerations. Journal of Educational Administration, 38(1):83-101.

SIMELANE, BS; KUNENE, PJ \& MHLONGO, CS 1997: Attitudes of nursing students towards the seminar method of teaching. Curationis, 20(1):11-14.

SMITH, WJ; HOWARD, JT \& HARRINGTON, KV 2005: Essential formal mentor characteristics and functions in governmental and non-governmental organizations from the program administrator's and the mentor's perspective. Public Personnel Management, 34(1):31-59.

TELLIS, W 1997: Introduction to the Case Study. Qualitative Report, 3(2). Available from www.nova.edu/ssss/QR/QR3-2/ tellis1.html (Accessed: 7 November 2004).

VAN ASWEGEN, EJ; BRINK, HI \& STEYN, PJ, 2000: A model for facilitation of critical reflective practice: Part I - Introductory discussion and explanation of the phases followed to construct the model. Part II - Conceptual analysis within the context of constructing the model. Part III - Description of the model. Curationis, 23(4):117-135.

WALTERS, DD; CLARKE, MM; INGALL, AAH \& DEAN-JONES, MM 2003: Evaluation of a pilot mentoring programme for nurse managers. Journal of Advanced Nursing, 42(5):516-526.

ZIEGAHN, L 2001: Considering culture in the selection of teaching approaches for adults. ERIC Digest. Available from ERIC Clearinghouse on Higher Education database: http://ericacve.org/ digests.asp (Accessed on 30 December 2002). 